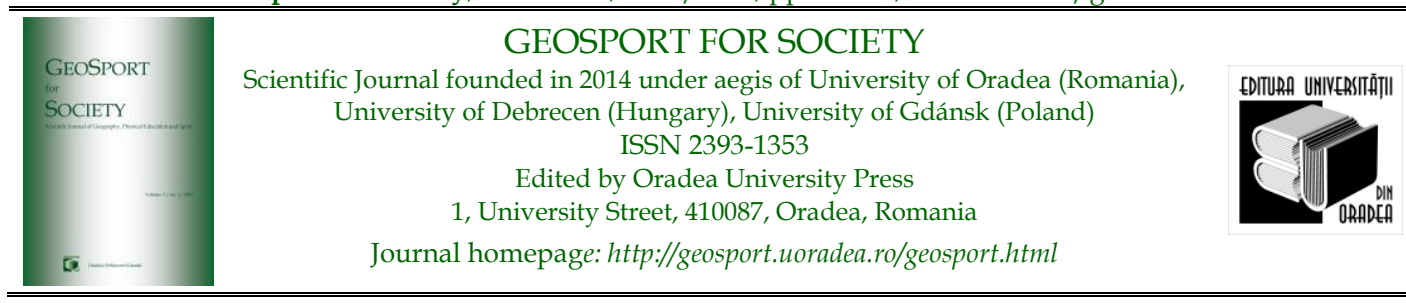

\title{
Cartographic representation of a sports (football) competition - UEFA Youth League (2013-2019)
}

\author{
Olivier DEHOORNE¹, Jan A. WENDT², Andrey MIKHAYLOV3, \\ Zharas BERDENOV4, Alexandru ILIEŞ5*
}

1. University of Antilles, Martinique, France, e-mail: dehoorneo@gmail.com

2. University of Gdansk, Poland, e-mail: jan.wendt@ug.edu.pl

3. Immanuel Kant Baltic Federal University, Russian Federation, e-mail: mikhailov.andrey@yahoo.com

4. L.N. Gumilyov Eurasian National University of Nur-Sultan, Kazakhstan, e-mail: berdenov-z@mail.ru

5. University of Oradea, Romania, e-mail: alexandruilies@gmail.com

* Corresponding author

Citation: Dehoorne, O., Wendt, J. A., Mikhaylov, A., Berdenov, Z., \& Ilieș, A. (2019). Cartographic representation of a sports (football) competition - UEFA Youth League (2013-2019). Geosport for Society, 11(2), 86-100. https://doi.org/10.30892/gss.1104-051

Article history: Received: 03.09.2019; Revised: 05.10.2019; Accepted: 12.11.2019, Available online: 21.11.2019

\begin{abstract}
The sports phenomenon, football in this case, is analyzed through the angle of the inter-clubs' European competition UEFA Youth League, for teams with players aged under 19. By means of the used cartographic methods, our purpose was to build a useful tool in elaborating territorial planning and development strategies, applicable on local, regional and even continental level. The spatial representation, through adjusted methods, of certain quantitative elements (reflected through number) combined with the qualitative ones (performance) in graphic and cartographic synthetic materials, set in chronological order, finalizes our endeavor with the elaboration of synthetic products of great practical utility. There are analyzed the affiliated federations, participating teams, represented localities etc., the relations between them, their temporal activity sequence and their performances. The resulting maps are thus representations of territorial realities and they faithfully portray the condition of the sports phenomenon through temporal sequences and through its spatial distribution, as a reflection of the support human society.
\end{abstract}

Keywords: sport team, competition, football, UEFA Youth League, under 19

\section{Introduction}

The increase of states number on European level after 1990 led to the increase of national teams' number, sports federations and, implicitly, sports clubs involved in European competitions affiliated to UEFA. In order to give an affirmation 
opportunity to as many young people (Atan et al., 2014) as possible the European football forum, besides the traditional senior competitions, founded in 1993 the UEFA Youth League for teams with players Under 19. By means of this study and the used cartographic representation methods (Griffin et al., 2017; Murphy, 2019), our purpose was to accomplish a spatial-temporal analysis tool for a sports competition (Bale, 2000; Herman et al., 2018). Its efficiency is provided by the combination of quantitative elements (number) with the qualitative ones (performances), with the possibility of chronological setting, into original, expressive (Raisch, 2018) and representative synthetic products (Ilieș et al., 2014; Cartwright \& Ruas, 2015), esspecialy in outlining the relationship between settlements and sport (Bale, 2002; Reilly and Gilbourne, 2003; Bale \& Vertinsky, 2004; Conner, 2014; Kozma et al., 2015). There are analyzed in space and time structural elements of a competition such as: seasonality, affiliated federations, registered clubs, representative localities, etc., all filtered through the quantitative-qualitative spatial-temporal analysis.

\section{Methodology}

The methodological component includes gathering real, verified and organized statistical information so it could be processed through GIS. Creating the data base (Robinson et al., 2017) usig the information from website ${ }^{1}$ facilitates later on, according to the elements taken into consideration, the mapping of the European football space generated by complex geographical and statistical elements of qualitative and quantitative importance (Reilly \& Gilbourne, 2003; Ilieș et al., 2014; Kozma et al., 2015; Herman et al., 2016a; Ilieș et al., 2016a; 2016b; 2016c) Thus, original maps are provided which, due to the methods and principles used in elaborating them (Ilieș et al., 2015; O'Brien \& Cheshire, 2016; Gartner \& Huang, 2016; Herman et al., 2016b; Roth et al., 2017; Raisch, 2018), are very useful in outlining in time and space of a certain phenomenon, event or sports competition (Bairner, 2011; Buhaș et al., 2017; Ilieș et al., 2015; Ilieș, et al., 2016a; Gaffney, 2016). Through the cartographic method and representation ways (dots, circles, cartograms, symbols, etc.), supported by GIS, there are shown quantitative and qualitative spatial-temporal aspects of elements forming the sports phenomenon (Henry, 2005; Shobe, 2008; Sam \& Hughson, 2010; Goldblatt, 2011; Ilies et al, 2016a; 2016b; 2016c; James \& Day, 2015; Wendt \& Scutti, 2016; Buhaș et al., 2018).

\section{Analitical component}

The spatial dimension of the international impact of youth football game (players under 19) on inter-clubs European competition level started to be outlined 
ever since the organization of the first edition of the UEFA Youth League competition. Practically, the affiliation of national federations and their representation though clubs formed of juniors under 19 represents a way of emphasizing the interest on club level for raising and promoting the young players. In almost every European country affiliated to UEFA (figure 1), irrespective of its dimensions and number of inhabitants, there is at least one national competition for clubs with youth teams.

\section{Chronology and spatiality}

Chronologically, 7 editions were analyzed (figure 1; table 1), out of which 6 were complete, while the last one (2019/2020) is still in progress. According with table 1 and figure 2 in all 7 editions paricipated 44 national footbal federations from 130 localities with 158 footbal clubs (table 1).

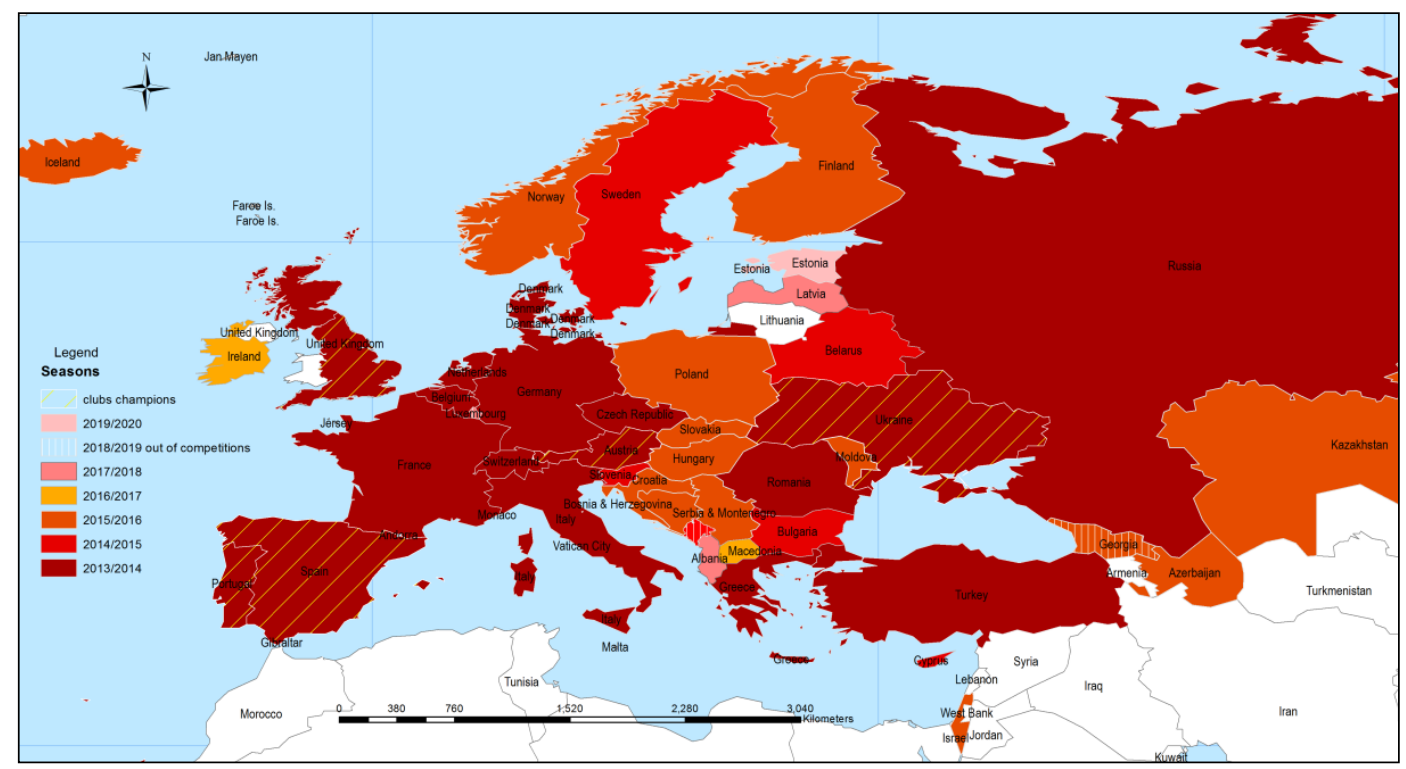

Figure 1. UEFA map. The national federation according with year (seson) of first participation in UEFA Youth League and teams champion ${ }^{1}$

The first UEFA Youth League competition season (2013/2014) gathered no less than 32 teams (table 1), representing 18 national footbal federations and 29 localities. Madrid, Manchester and London had two teams each. The best represented federation was England, Germany, Italy and Spain with 4 teams each, followed by France, Portugal and Russia with 2 club teams. The competition format included preliminary elimination tournaments. As expected, 4 clubs with tradition from countries with advanced football reached the semifinals: FC Barcelona (first champion), Benfica Lisabona, Schalke 04 Gelsenkirchen, Real Madrid (figure 8; table 2). 
Table 1. The national football federation, localities and number of clubs with participation in UEFA Youth League between 2013-2019 1

\begin{tabular}{|c|c|c|c|c|c|c|c|c|c|c|c|c|c|c|c|c|c|}
\hline \multirow{3}{*}{ no } & \multirow{3}{*}{$\begin{array}{c}\text { National } \\
\text { Footbal } \\
\text { Federation }\end{array}$} & \multicolumn{2}{|c|}{$\begin{array}{c}\text { Season } \\
2013 / 20 \\
14\end{array}$} & \multicolumn{2}{|c|}{$\begin{array}{c}\text { Season } \\
2014 / 20 \\
15\end{array}$} & \multicolumn{2}{|c|}{$\begin{array}{c}\text { Season } \\
2015 / 20 \\
16\end{array}$} & \multicolumn{2}{|c|}{$\begin{array}{c}\text { Season } \\
2016 / 20 \\
17\end{array}$} & \multicolumn{2}{|c|}{$\begin{array}{c}\text { Season } \\
2017 / 20 \\
18\end{array}$} & \multicolumn{2}{|c|}{$\begin{array}{c}\text { Season } \\
2018 / 20 \\
19\end{array}$} & \multicolumn{2}{|c|}{$\begin{array}{c}\text { Season } \\
2019 / 20 \\
20\end{array}$} & \multicolumn{2}{|c|}{ Total } \\
\hline & & \multicolumn{16}{|c|}{ Number of } \\
\hline & & $\begin{array}{c}\text { Settle } \\
\text { ment } \\
s \\
1 \\
\end{array}$ & $\begin{array}{c}\text { Team } \\
s \\
2\end{array}$ & 1 & 2 & 1 & 2 & 1 & 2 & 1 & 2 & 1 & 2 & 1 & 2 & 1 & 2 \\
\hline 1 & Albania & & & & & & & & & 1 & 1 & 1 & 1 & 1 & 1 & 1 & 1 \\
\hline 2 & Austria & 1 & 1 & & & 1 & 1 & 1 & 1 & 1 & 1 & 1 & 1 & 1 & 1 & 2 & 3 \\
\hline 3 & Azerbaijan & & & & & 1 & 1 & 1 & 1 & 1 & 1 & 1 & 1 & 1 & 1 & 2 & 3 \\
\hline 4 & Belarus & & & 1 & 1 & 2 & 2 & 1 & 1 & 1 & 1 & 1 & 1 & 1 & 1 & 3 & 4 \\
\hline 5 & Belgium & 1 & 1 & 1 & 1 & 2 & 2 & 2 & 2 & 1 & 1 & 2 & 2 & 2 & 2 & 3 & 3 \\
\hline 6 & $\begin{array}{l}\text { Bosnia and } \\
\text { Hercegovina }\end{array}$ & & & & & 1 & 1 & 1 & 1 & 1 & 1 & & & 1 & 1 & 2 & 2 \\
\hline 7 & Bulgaria & & & 1 & 1 & 1 & 1 & 2 & 2 & 1 & 1 & 1 & 1 & 1 & 1 & 3 & 4 \\
\hline 8 & Cyprus & & & 1 & 1 & 1 & 1 & 1 & 1 & 1 & 1 & 1 & 1 & 1 & 1 & 2 & 2 \\
\hline 9 & Croatia & & & & & 1 & 1 & 1 & 1 & 1 & 1 & 1 & 1 & 1 & 1 & 1 & 2 \\
\hline 10 & Czech Rep. & 1 & 1 & & & 1 & 1 & 1 & 1 & 1 & 1 & 2 & 2 & 1 & 1 & 4 & 5 \\
\hline 11 & Denmark & 1 & 1 & & & 2 & 2 & 1 & 1 & 1 & 1 & 1 & 1 & 1 & 1 & 3 & 3 \\
\hline 12 & England & 2 & 4 & 3 & 5 & 3 & 5 & 3 & 4 & 3 & 4 & 3 & 5 & 4 & 5 & 6 & 9 \\
\hline 13 & Estonia & & & & & & & & & & & & & 1 & 1 & 1 & 1 \\
\hline 14 & Finland & & & & & 1 & 1 & 1 & 1 & 1 & 1 & 1 & 1 & 1 & 1 & 2 & 3 \\
\hline 15 & France & 2 & 2 & 2 & 2 & 3 & 3 & 3 & 3 & 3 & 3 & 4 & 4 & 4 & 4 & 9 & 9 \\
\hline 16 & Georgia & & & & & 1 & 1 & 1 & 1 & 1 & 1 & & & & & 1 & 2 \\
\hline 17 & Germany & 4 & 4 & 4 & 4 & 5 & 5 & 4 & 4 & 3 & 3 & 5 & 5 & 4 & 4 & 9 & 9 \\
\hline 18 & Greece & 1 & 1 & 1 & 1 & 1 & 1 & 1 & 1 & 1 & 1 & 2 & 2 & 2 & 2 & 3 & 3 \\
\hline 19 & Hungary & & & & & 1 & 1 & 1 & 1 & 1 & 1 & 1 & 1 & 1 & 1 & 2 & 4 \\
\hline 20 & Iceland & & & & & 1 & 1 & 1 & 1 & 1 & 1 & 1 & 1 & 1 & 1 & 2 & 4 \\
\hline 21 & Ireland & & & & & & & 1 & 1 & 1 & 1 & 1 & 1 & 1 & 1 & 2 & 3 \\
\hline 22 & Israel & & & & & 1 & 1 & 1 & 1 & 1 & 1 & 1 & 1 & 1 & 1 & 3 & 3 \\
\hline 23 & Italy & 4 & 4 & 2 & 2 & 2 & 3 & 3 & 3 & 4 & 4 & 4 & 4 & 4 & 4 & 5 & 7 \\
\hline 24 & Kazahstan & & & & & 2 & 2 & 1 & 1 & 1 & 1 & 1 & 1 & 1 & 1 & 3 & 3 \\
\hline 25 & Latvia & & & & & & & & & 1 & 1 & & & 1 & 1 & 1 & 1 \\
\hline 26 & Luxembourg & & & & & & & & & 1 & 1 & & & 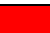 & & 1 & 1 \\
\hline 27 & $\begin{array}{l}\text { Northern } \\
\text { Macedonia }\end{array}$ & & & & & & & 1 & 1 & 1 & 1 & & & 1 & 1 & 2 & 2 \\
\hline 28 & Moldova & & & & & 1 & 1 & 1 & 1 & 1 & 1 & 1 & 1 & 1 & 1 & 2 & 2 \\
\hline 29 & Montenegro & & & & & & & 1 & 1 & 1 & 1 & & & 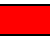 & & 2 & 2 \\
\hline 30 & Netherlands & 1 & 1 & 1 & 1 & 2 & 2 & 2 & 2 & 2 & 2 & 2 & 2 & 1 & 1 & 3 & 3 \\
\hline 31 & Norway & & & & & 1 & 1 & 1 & 1 & 1 & 1 & 1 & 1 & 1 & 1 & 4 & 4 \\
\hline 32 & Poland & & & & & 1 & 1 & 1 & 1 & 1 & 1 & 1 & 1 & 1 & 1 & 3 & 3 \\
\hline 33 & Portugal & 2 & 2 & 2 & 3 & 2 & 2 & 1 & 2 & 2 & 3 & 2 & 2 & 2 & 2 & 2 & 3 \\
\hline 34 & Romania & 1 & 1 & & & 1 & 1 & 1 & 1 & 1 & 1 & 1 & 1 & 1 & 1 & 2 & 3 \\
\hline 35 & Russia & 2 & 2 & 2 & 2 & 2 & 3 & 2 & 3 & 2 & 3 & 2 & 3 & 2 & 2 & 4 & 7 \\
\hline 36 & Scotland & 1 & 1 & & & 1 & 1 & 1 & 1 & 1 & 1 & 1 & 1 & 1 & 1 & 2 & 3 \\
\hline 37 & Serbia & & & & & 1 & 1 & 1 & 1 & 1 & 1 & 1 & 1 & 1 & 1 & 3 & 4 \\
\hline 38 & Slovakia & & & & & 1 & 1 & 1 & 1 & 1 & 1 & 1 & 1 & 1 & 1 & 4 & 4 \\
\hline 39 & Slovenia & & & 1 & 1 & 1 & 1 & 1 & 1 & 1 & 1 & 1 & 1 & 1 & 1 & 2 & 2 \\
\hline 40 & Spain & 3 & 4 & 3 & 4 & 5 & 6 & 4 & 5 & 3 & 4 & 3 & 4 & 4 & 5 & 9 & 10 \\
\hline 41 & Sweden & & & 1 & 1 & 2 & 2 & 1 & 1 & 1 & 1 & 1 & 1 & 1 & 1 & 3 & 4 \\
\hline 42 & Switzerland & 1 & 1 & 1 & 1 & 1 & 1 & 2 & 2 & 1 & 1 & 2 & 2 & 1 & 1 & 4 & 4 \\
\hline 43 & Turkey & 1 & 1 & 1 & 1 & 1 & 2 & 2 & 2 & 2 & 2 & 2 & 2 & 1 & 1 & 3 & 4 \\
\hline 44 & Ukraine & 1 & 1 & 1 & 1 & 2 & 2 & 1 & 1 & 2 & 2 & 2 & 2 & 2 & 2 & 2 & 2 \\
\hline & TOTAL & 29 & 32 & 28 & 32 & 57 & 63 & 57 & 61 & 57 & 61 & 58 & 62 & 59 & 61 & 130 & 158 \\
\hline
\end{tabular}

The second edition $(2014 / 2015)$ had the same format (32 teams), but with a higher number of represented federations (18) with 28 localities. Thus, club teams from Belarus, Bulgaria, Cyprus, Slovenia and Sweden entered the 
competition, but countries like Austria, Czech Republic, Denmark, Romania and Scotland were not represented (table 1).

The third edition (2015/2016) "conquered" and extended the football playing Europe through significant increase of the number of represented countries (to 37), as well as of clubs to 63 and 57 localities (figure 1; table 1). The 13 new states were the following: Azerbaijan, Bosnia-Hercegovina, Croatia, Georgia, Hungary, Iceland, Israel, Kazakhstan, Moldova, Norway, Poland, Serbia and Slovakia.

A significant number of federations entered more than two teams into the competition. The format was different as well (figure 3). 32 teams participated in three preliminary tournaments, while other 32 teams from countries with high coefficients on senior level participated in parallel to a competition under the form of 8 teams.

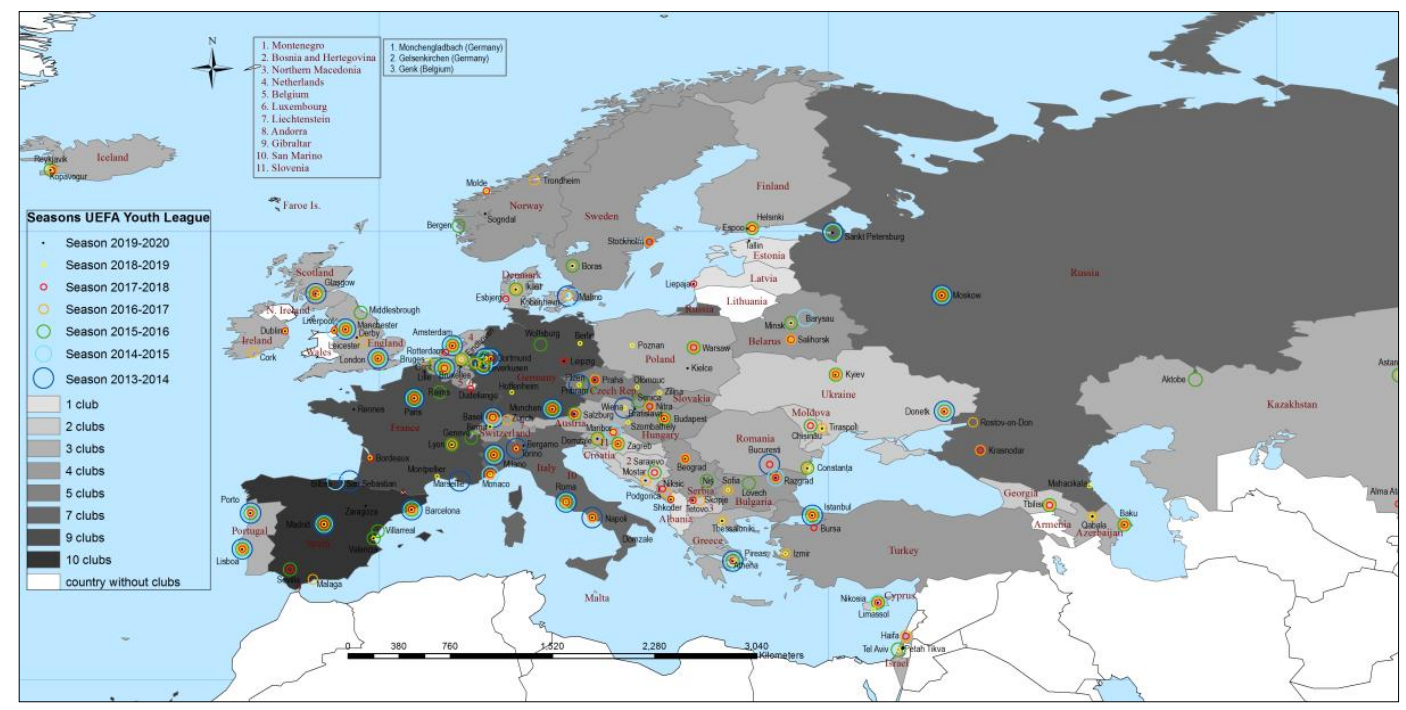

Figure 2. UEFA map. The national football federation, number of football clubs and settlements with teams participation in UEFA Youth League between 2013-2019 1

The winners of the 8 groups were qualified in the quarterfinals. The teams ranked on the second places in groups entered the playoffs with the teams qualified after the second preliminary tournament. The quarterfinals, semifinals and the final followed. For the third edition, the final four was made up of Chelsea (champion), Paris Saint Germain (PSG), Anderlecht Bruxelles and Real Madrid (figure 8; table 2).

In the fourth edition (2016/2017) had 61 federation with 61 clubs from 57 localities. The first tournament included 32 teams and two new states: Northern Macedonia and Montenegro. After the first tournament, 16 teams remained. After the second tournament, 8 teams entered the playoffs and other 8 teams joined 
them, those ranked on the second places in groups. In the fourth edition, 3 clubs with tradition "relapsed": Benfica, CF Barcelona and Real Madrid, however, the champion was a surprise team from Austria: FC Salzburg, winner in the final against Lisbon (table 2).

New federations entered the 2017/2018 edition (5): Albania, Latvia and Luxemburg and, implicitly, the number of localities (57) and of representative teams (61) increased (figures 1 and 3). On this edition participated maximum number of federation, 43 (table 1).

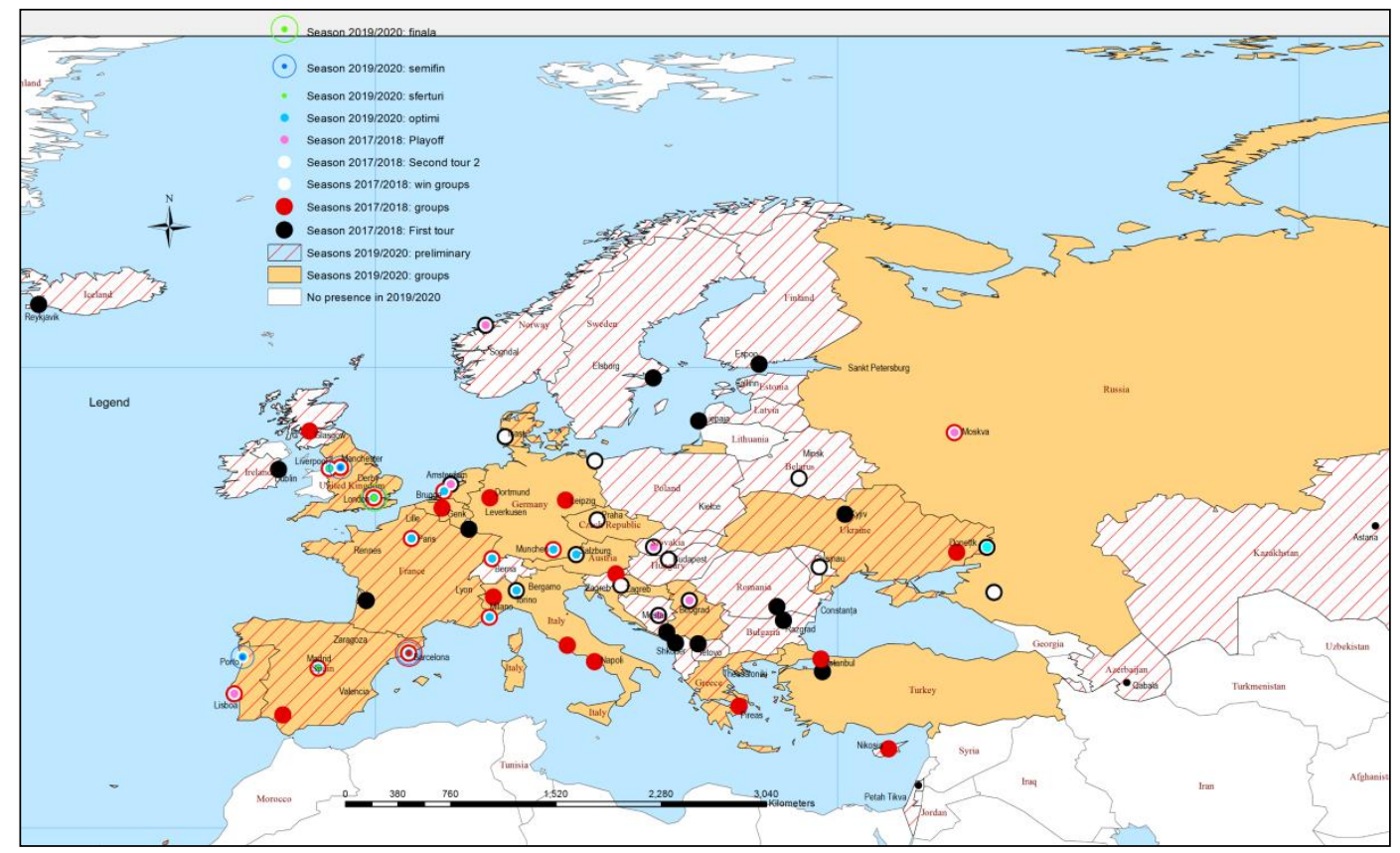

Figure 3. UEFA map. Spatial distribution of the preliminary and groups phase of the $2017 / 2018$ in UEFA Youth League 1

The sixth edition (2018/2019), in the same format, ended in the summer of 2019 and brought under the lights the team FC Porto, followed by Chelsea, FC Barcelona and Hoffenheim. In the quarterfinals, the following teams were ranked on the places from 5 to 8: Dynamo Zagreb, Olimpique Lyon, Real Madrid and Midtylland Inkast. Number of federation decrease to 37 with 62 clubs from 58 localities.

The last edition, 2019/2020, represented by 41 national federations being in progress, includes 61 teams from 59 localities distributed in the preliminary phase in 8 groups and, in parallel, in two eliminatory tournaments. In the figure 3, it is cartographically represented the spatial distribution of the preliminary phase of the 2019/2020 competition. 


\section{Spatiality and the quantitative component}

Ever since the 2013/2014 edition, a number of 32 teams, representing 18 European states (table 1) (re)configured the European space (figures 1 and 4) having as criterion the participation of affiliated clubs to the first edition of UEFA YL. At the initiative of inter-clubs European football important forces, the best represented national federations were: England, Germany, Spain and Italy with 4 teams each, Portugal, Russia and France with 2 teams each and Ukraine, Turkey, Switzerland, Scotland, Romania, Holland, Greece, Denmark, Czech Republic, Belgium and Austria with one team each (figure 4). Gradually, the number of participating federations increased to 44 in the 2018/2019 edition, out of the 55 teams entered in UEFA (figures 2,4 ; table 1 ).

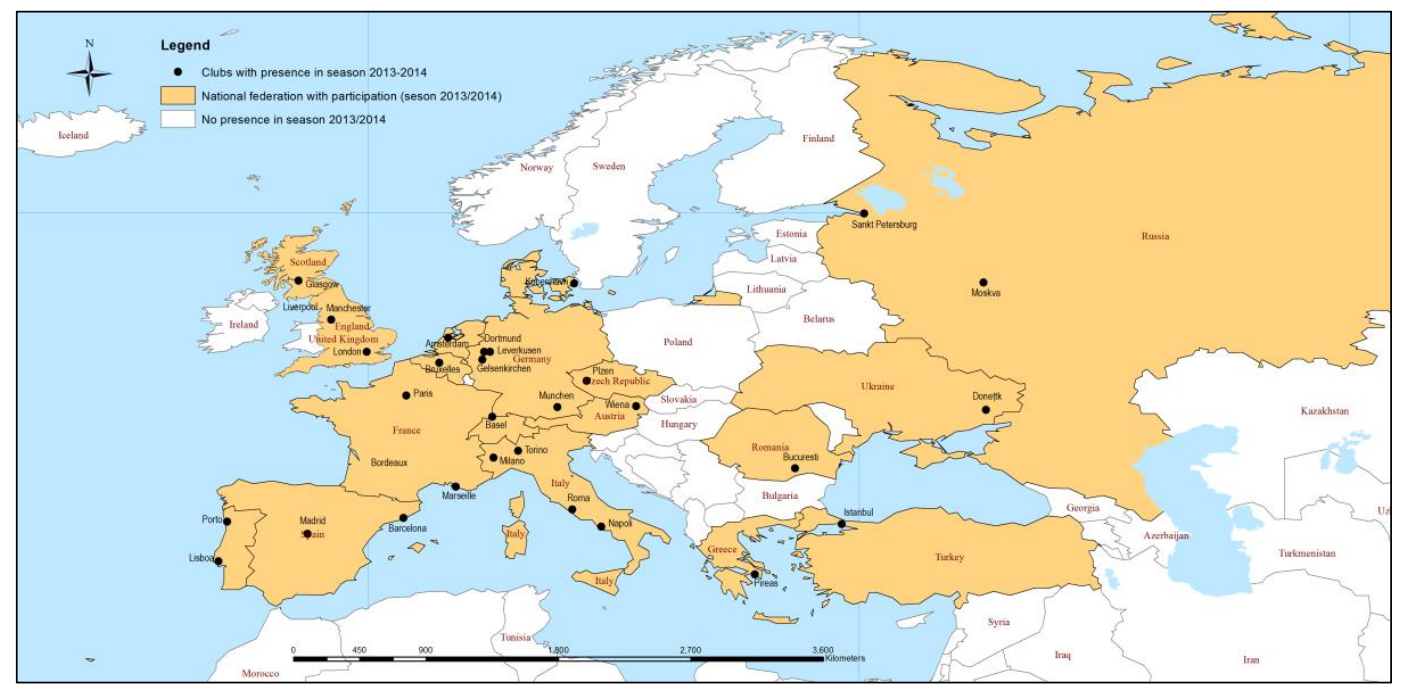

Figure 4. UEFA map. Spatial distribution of national federations and localities with participation in first sezon $(2013 / 2014)$ in UEFA Youth League 1

In figure 1, the European football fethederations were represented in chronological order after the year of the first participation in this competition. Up to present, 11 national federations participating to the inter-clubs senior European competitions have not entered any club teams into this competition: Andorra, Armenia, Faeroe Gibraltar, Islands, Kosovo, Liechtenstein, Lithuania, Malta, Northern Ireland, San Marino and Wales. It should also be mentioned that, out of political or economic reasons, UEFA entered in its own competitions extraEuropean federations such as Armenia, Azerbaijan, Georgia, Israel and Kazakhstan (figure 1). 


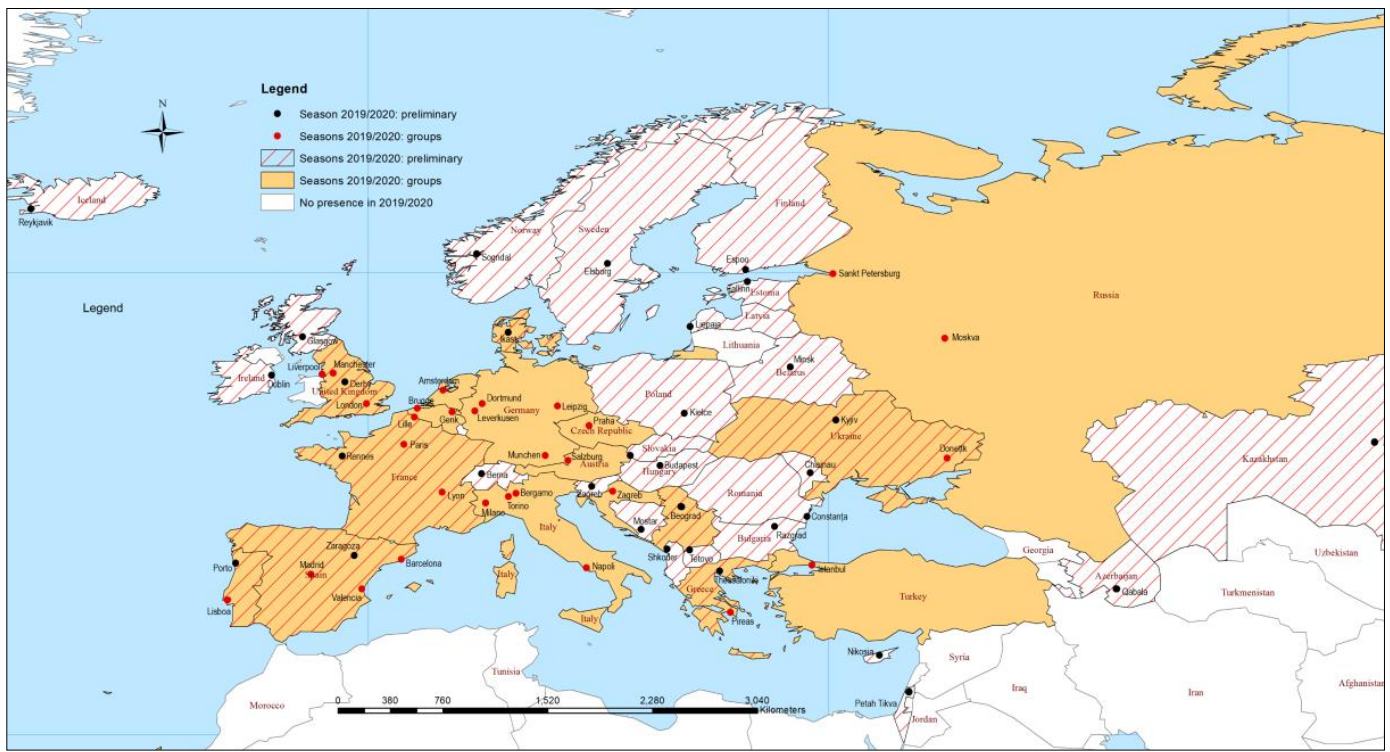

Figure 5. UEFA map. Spatial distribution of the preliminary phase of the 2019/2020 in UEFA Youth League ${ }^{1}$

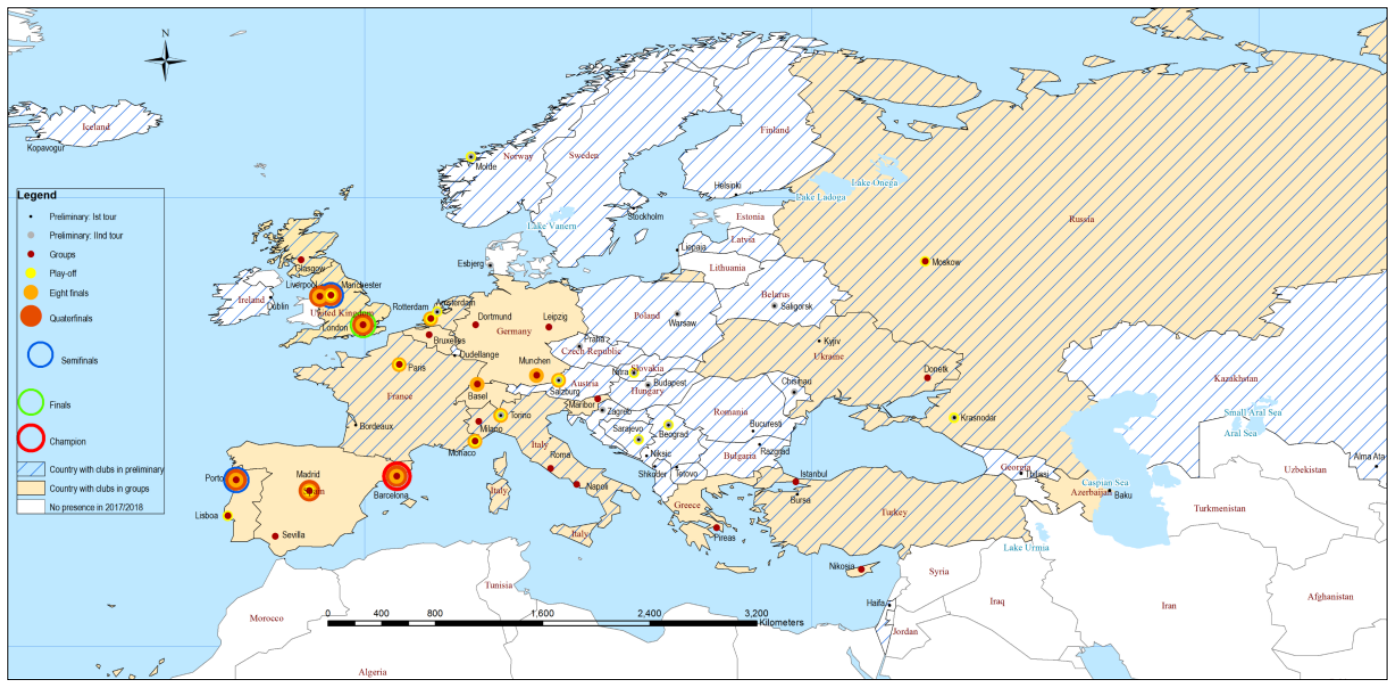

Figure 6. UEFA map. Spatial distribution of the preliminary phase of the 2017/2018 in UEFA Youth League ${ }^{1}$

Out of the 7 editions, the most complete one was the $2017 / 2018$ edition with the participation of 43 national federations. Compared to the previous editions, the federations from Luxemburg, Georgia and Montenegro did not enter any club teams into the 2019/2020 edition. Thus, on the 2019 map (figure 6), 41 national federations are represented.

An interesting aspect to be cartographically represented is the competition management manner through its organization form. For example, in editions 
$2017 / 2018$ (figure 3) and 2019/2020 (figure 5), thus, two categories of countries, teams and represented localities are identified:

- teams participating in preliminary elimination tournaments (32 teams in two tournaments);

- teams participating in competition groups (32 groups divided in 8 groups $\mathrm{x} 4$ teams each);

The superior phases include (figure 6):

-16 teams in the quarterfinals (eliminatory): the 8 winning teams of the second preliminary tournament were matched with 8 teams from the second places in the groups. After this tournament, 8 teams remain;

-16 teams in the eighths of finals: the winners of the 8 groups and the 8 teams qualified from playoff;

The end of the competition includes quarterfinals, semifinals and big final.

\section{Quality and spatiality}

\section{Spatial distribution of the sports phenomenon}

a) The method of cartograms and the color spectrum used in the cartographic construction from figure 7 show the spatial distribution of a series of data over 7 years with competition specific elements on country level such as: football federations participating through clubs entered into competitions; the year they entered the competition; the year (years) when they did not participate to the competition; the number of participations since the competition for under 19 club teams was founded. At the same time, the map mirrors faithfully the youth football representativeness on European states level. For example, regarding the oldness in competition, there are two areas outlined on the map (figures 1, 2 and 7): a western one, made up of countries representative for European football (12 federations) and an eastern one encompassing countries from the former socialist block: Russia, Ukraine and Romania, to which Turkey and Greece are added in the south-east. Amongst these, a Central European group occurs, from the Mediterranean to the Baltic Sea, connected with the Scandinavian area. Kazakhstan and the Caucasian countries close up the European football space in the south-east. In conclusion, figures 1, 2 and 7 shows quite faithfully the spatial distribution of "European football forces", pointing out that they can also be found dominantly in inter-club youth (under 19) football competitions.

b) Through the method of points and circles to scale, there can be represented the quantitative dimension of the sports phenomenon (teams, localities, etc.) and the qualitative one (performance, oldness, etc). Figures 1, 2 and 7 shows spatially all centers on level of locality and sports federation which participated with club teams to all the 7 editions of UEFA Youth League. Thus, the 
position of the point or of the circle shows the represented locality and the dimension of the point or of the circle shows the number of teams in the respective locality. Other elements, represented through different colors, can be added, such as: the edition or the number of editions (figure 2). A brief analysis of the 7 editions emphasizes a series of aspects such as (figure 2):

- 44 national federations were represented; the number of participating teams was 158; the number of represented localities was 130;

- the following localities had the highest number of teams: London (3), Budapest (3), Moscow (4), Belgrade (3), while Wienn, Minsk, Sofia, Bucharest, Prague, Manchester, Helsinki, Tbilisi, Reykjavik, Dublin, Torino, Milano, Lisbon, Madrid, Glasgow, Stockholm and Istanbul had 2 teams each. To these, other 120 localities are added with one team each.

- the highest number of localities were in the following countries: France (9), Germany (9), Spain (9), England (6), Italy (5) etc.

- the highest number of teams had federations from: Spain (10), and 9 football clubs England, France and Germany.

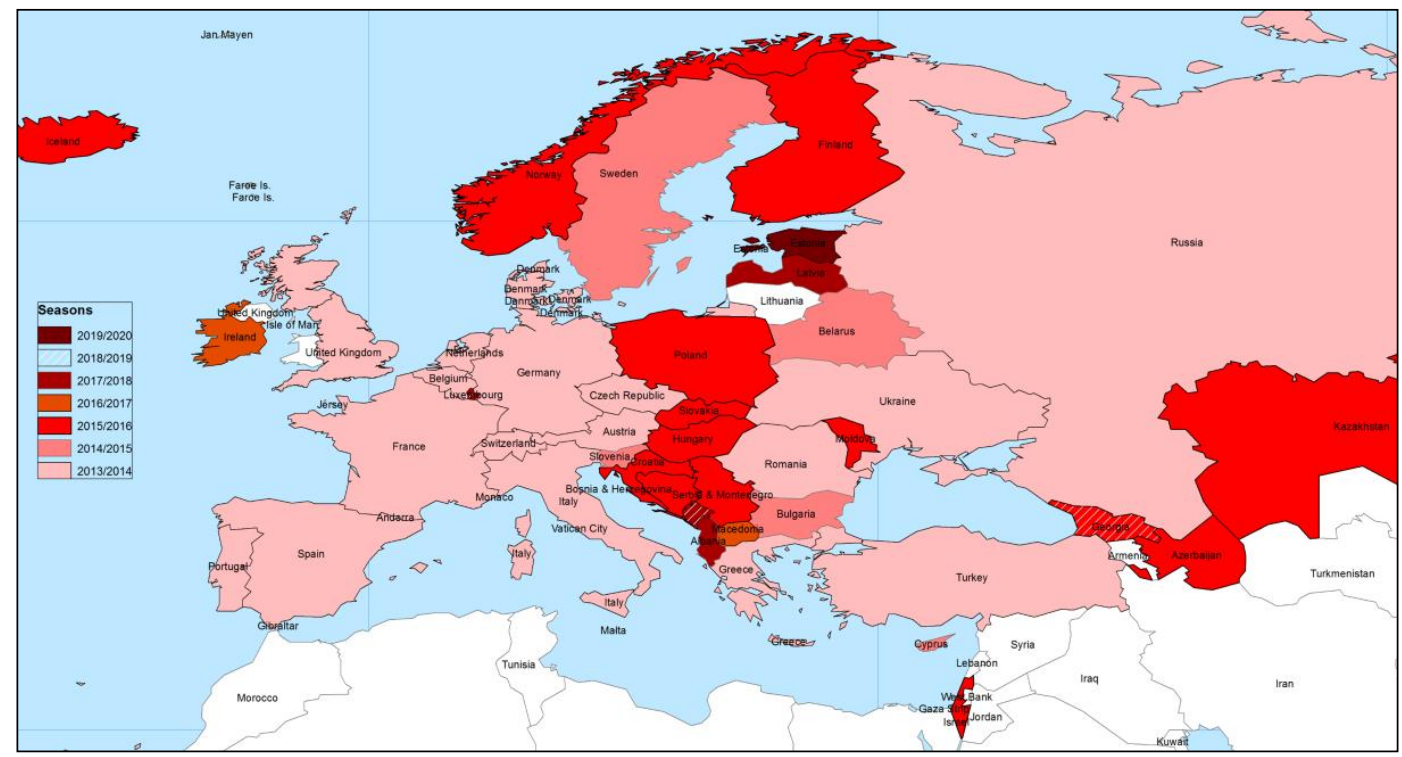

Figure 7. UEFA map. The national federation according with year (seson) of first participation in UEFA Youth League and teams champion ${ }^{1}$

To these, there can be added a series of other pieces of information generated by the combination of quantitative (number) type of elements with the qualitative ones (performances) and their spatial distribution. 
Another interesting aspect is provided by the spatial concentration map of the youth sports phenomenon determined by two directions:

-polycentric development (several clubs from the same locality: Madrid, London, Moscow etc.), typically for England, Spain, Russia etc

-or the spatial one (one club and one represented locality), typically for Germany, Italy etc.

\section{Quality through representation in the superior competition phases}

Combining the cartograms method with the points method in figure 2-9, the cartographic representation shows, on the spatial distribution background, the performing federations and the positioning on the places 1-8 in the 7 competition seasons of the participating club teams. On the level of the 7 editions, a qualitative aspect results from the cartographic representation of the first 8 qualified teams (quarterfinals). Through the representation method, the country, the number of participations, the place taken, etc, are all outlined by overlapping a series of 7 maps (for each edition) in the synthesis map of representation in the superior competition phases (table 2; figures 2 and 8). According to the detail degree, this representation manner can be with one element (the champion) or $\mathrm{n}$ elements (level of competition: semifinals, quarterfinals, eighths of finals, etc).

Table 2. The first 8 qualified teams (quarterfinals) in UEFA Youth League 1

\begin{tabular}{|c|l|l|l|l|l|l|}
\hline Place & \multicolumn{1}{|c|}{$\begin{array}{c}\text { Season } \\
\mathbf{2 0 1 3 / 2 0 1 4}\end{array}$} & \multicolumn{1}{|c|}{$\begin{array}{c}\text { Season } \\
\mathbf{2 0 1 4 / 2 0 1 5}\end{array}$} & $\begin{array}{c}\text { Season } \\
\mathbf{2 0 1 5} / \mathbf{2 0 1 6}\end{array}$ & $\begin{array}{c}\text { Season } \\
\mathbf{2 0 1 6 / 2 0 1 7}\end{array}$ & $\begin{array}{c}\text { Season } \\
\mathbf{2 0 1 7} / \mathbf{2 0 1 8}\end{array}$ & $\begin{array}{c}\text { Season } \\
\mathbf{2 0 1 8} / \mathbf{2 0 1 9}\end{array}$ \\
\hline $\mathbf{1}$ & CF Barcelona & Chelsea London & $\begin{array}{l}\text { Chelsea } \\
\text { London }\end{array}$ & FC Salzburg & CF Barcelona & FC Porto \\
\hline 2 & $\begin{array}{l}\text { Benfica } \\
\text { Lisabona }\end{array}$ & Sahtior Doneț & Paris SG & Benfica Lisabon & $\begin{array}{l}\text { Chelsea } \\
\text { London }\end{array}$ & $\begin{array}{l}\text { Chelsea } \\
\text { London }\end{array}$ \\
\hline $3-4$ & $\begin{array}{l}\text { Schalke } 04 \\
\text { Gelsenkirchen }\end{array}$ & $\begin{array}{l}\text { Anderlecht } \\
\text { Bruxelles }\end{array}$ & Real Madrid & CF Barcelona & FC Porto & CF Barcelona \\
\hline $3-4$ & Real Madrid & AS Roma & $\begin{array}{l}\text { Anderlecht } \\
\text { Bruxelles }\end{array}$ & Real Madrid & $\begin{array}{l}\text { Manchester } \\
\text { City }\end{array}$ & Hoffenheim \\
\hline $5-8$ & $\begin{array}{l}\text { Manchester } \\
\text { City }\end{array}$ & Benfica Lisboa & Ajax Amsterdam & $\begin{array}{l}\text { Ajax } \\
\text { Amsterdam }\end{array}$ & $\begin{array}{l}\text { Athletico } \\
\text { Madrid }\end{array}$ & $\begin{array}{l}\text { Dinamo } \\
\text { Zagreb }\end{array}$ \\
\hline 6 & Paris SG & Manchester City & $\begin{array}{l}\text { Benfica } \\
\text { Lisabona }\end{array}$ & $\begin{array}{l}\text { Athletico } \\
\text { Madrid }\end{array}$ & FC Liverpool & $\begin{array}{l}\text { Olympique } \\
\text { Lyon }\end{array}$ \\
\hline 7 & $\begin{array}{l}\text { Arsenal } \\
\text { London }\end{array}$ & Atheltico Madrid & CF Barcelona & $\begin{array}{l}\text { CSKA } \\
\text { Moscova }\end{array}$ & Real Madrid & Real Madrid \\
\hline 8 & $\begin{array}{l}\text { Chelsea } \\
\text { London }\end{array}$ & FC Porto & AS Roma & FC Porto & $\begin{array}{l}\text { Totenham } \\
\text { Hotspur }\end{array}$ & $\begin{array}{l}\text { Midtjiylland } \\
\text { Ikast }\end{array}$ \\
\hline
\end{tabular}

On the level of final teams (table 1, figure 8), 7 federations were represented in the semifinals: Spain, Portugal, England, Austria, Germany, Belgium and Ukraine, and the winners were: England (2), Spain (2), Austria (1) and Portugal (1). Through the method of points, there are represented the localities with teams 
which obtained a ranking in the first 8 teams in the 7 competition seasons. Analytically, the following data stand out:

- 4 teams (CF Barcelona 2, Chelsea London 1, FC Salzburg 1 and FC Porto 1) from 4 localities (Barcelona, London, Salzburg and Porto), belonging to 4 distinct federations (England, Austria, Portugal and Spain) dominated the competition by winning the 6 champion titles of UEFA Youth League.

- except the Londoners from Chelsea (3 editions), other 3 teams (Sahtior, Paris SG and Benfica) from 3 localities (Donetsk, Paris and Lisbon) raised the number to 5 federations (the winners together with France and Ukraine) which played the 6 finals.

- out of the 5 finalist federations, only Portugal participated with 2 teams (FC Porto and Benfica) from 2 different localities (Lisbon and Porto), only FC Porto being a winner.

- regarding the semifinals and the occupants of places 3-4, next to the already "traditional" teams mentioned in the finals, the participating federations map is extended and includes 3 new states (Belgium, Germany and Italy), together with traditional ones: England, Spain, and Portugal, 6 new teams (Schalke 04, Real Madrid, Anderlecht, AS Roma, Manchester City and Hoffenheim) and 6 different localities (Gelsenkirchen, Madrid, Bruxelles, Roma, Manchester and Hoffenheim).

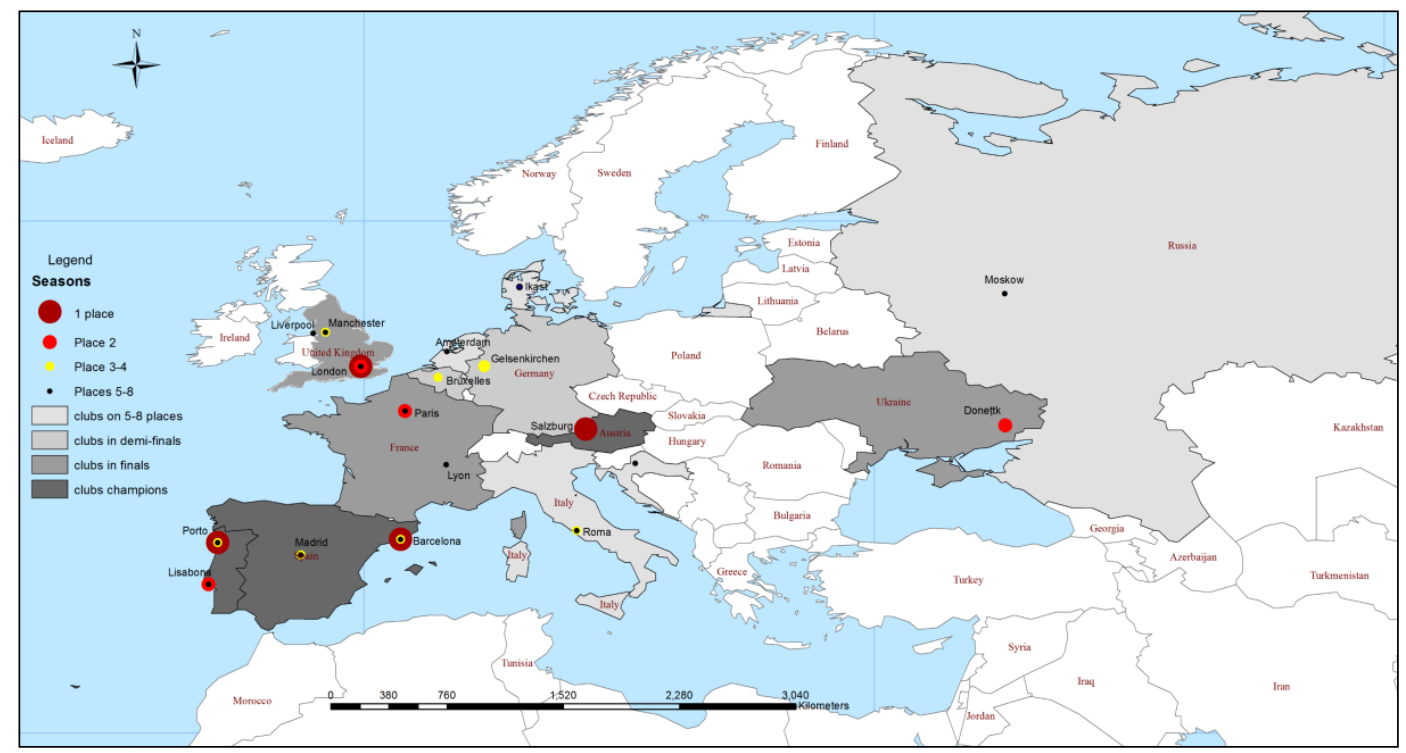

Figure 8. UEFA map. Performance, measured through the qualification among the first 8 teams in all seasenos of UEFA Youth League (2013-2019) ${ }^{1}$

- amongst the aces of the 6 finalized editions, we found 13 teams (table 2) on the 24 theoretically available places, most of them being with the teams CF Barcelona (4), Chelsea (4), Real Madrid (3), Anderlecht and Porto with 2 each. Regarding the cities, 
the followings stand out as polarizing centers: Barcelona (4), London (4) and federation wise, only 8 of the European ones occur: Spain (7), England (4) and Portugal (4), Germany (2), Austria, Belgium, Italy and Ukraine with one each.

- the places 5-8 extend the participation map with 4 more federations (Denmark, Russia, Netherlands and Croatia), with 8 new teams (Arsenal London, Atletico Madrid, Midlytdian Ikast, Dinamo Zagreb, CSKA Moscow, FC Liverpool, Ajax Amsterdam, Totenham London), next to the 8 traditional ones, and 6 new localities (Amsterdam, Moscow, Lyon, Zagreb, Ikast and Liverpool).

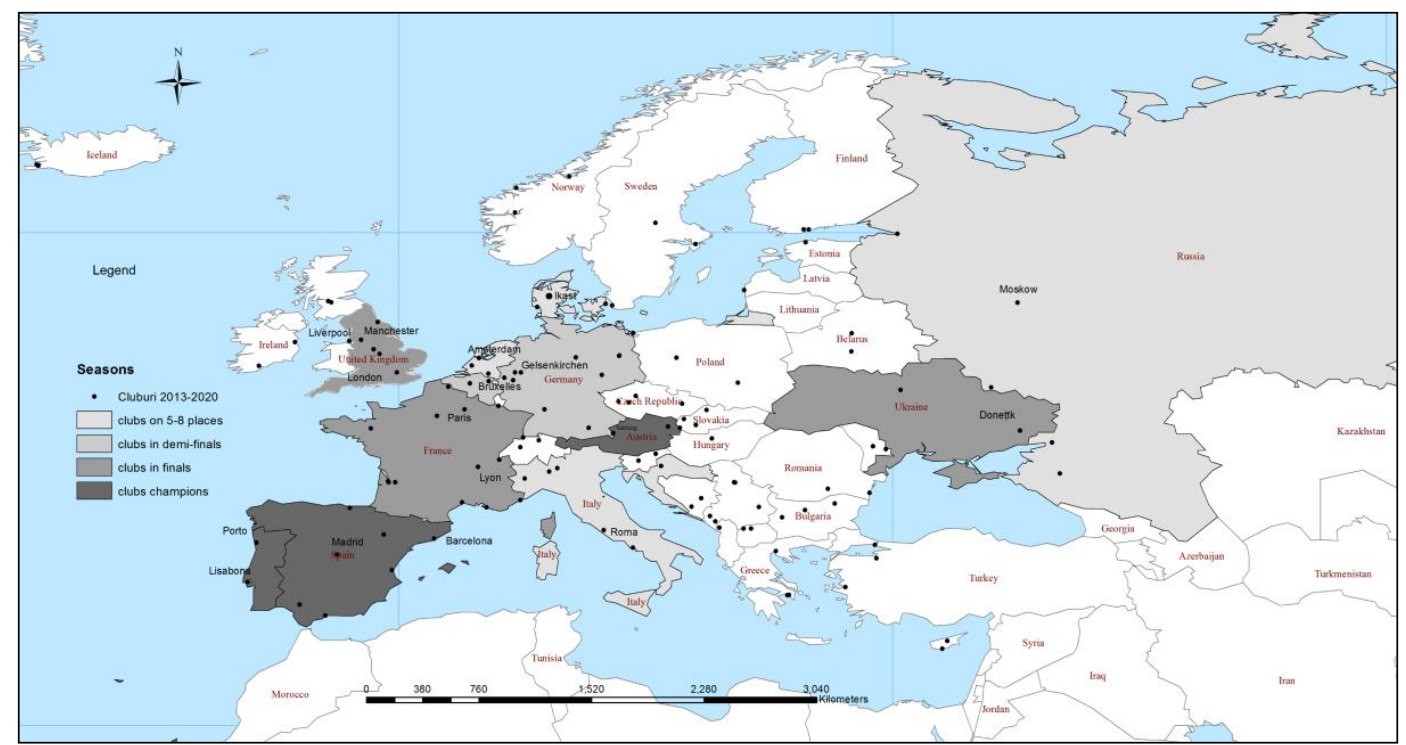

Figure 9. UEFA map. Performance of national federations, measured through the qualification among the first 8 teams in all seasenos of UEFA Youth League (2013-2019) ${ }^{1}$

Performance, measured through the qualification among the first 8 teams (out of 64 participants per edition), stands out on the level of 12 federations with 20 teams, representing 13 localities.

All these qualitative-quantitative elements are faithfully represented on map 1 which can be a good analysis tool in elaborating space development strategies of a sports phenomenon.

\section{Conclusions}

Spatial-temporal patterning through cartographic representation of a sports competition can significantly contribute as support to its development strategies elaboration. Through the properly chosen cartographic and graphic methods, a large number of elements can be shown, individually or synthetically, through the 
outcomes resulted from their combination. Thus, there can be shown many quantitative elements whose spatial distribution reflects the amplitude of the phenomenon in a given area. The complexity of the spatial analysis can increase by combining qualitative aspects (performances) with the quantitative ones (number), to which the temporal component is added. The case study focused on UEFA Youth League competition reflects, through the cartographically represented materials, the polarization centers of the phenomenon on country, club and locality levels. On the level of the 7 editions of analyzed competitions, 44 represented federations entered no less than 158 club teams, representing 130 European localities. Performance wise, referring to the ranking on the first 8 places during each edition, only 12 federations out of 44 were represented, while the number of localities was 12 out of 130. Through the data base elaborated with the representation methods chosen as appropriate for our endeavor, the resulting product, the map, represents a very useful tool due to the fact that it provides the possibility of a real spatial analysis, quantitative-qualitative comparisons, emphasizing certain elements from simple to complex and, especially, the ability to synthesize and spatially show elements and processes useful in elaborating territorial planning strategies from local to general level (European in the present case).

\section{References}

Atan, S. A., Foskett, A., \& Ali, A. (2014). Special populations: Issues and considerations in youth soccer match analysis. Int J Sports Sci, 4, 103-114.

Bairner, A. (2011). Soccer and Society in Eva Menasse's Vienna. Sport in history, 31(1), 32-48.

Bale, J. (2000). The changing face of football: Stadiums and communities. Soccer \& Society, 1(1), 91-101. Bale, J. (2002). Sports geography. Routledge.

Buhaș, D. S., Herman, G. V., Paul, F. D., \& Stance, L. (2017). Football and economy before and after communism in Romania. GeoSport for Society, 6(1), 30-39.

Buhaș, S., Ștef, M., Negruț, E., Herman, G. (2018). Aspects regarding the physical training level of "CSL Sporting Lugaș" female football team during the competitive year 2017-2018. Geosport for Society, $9(2), 63-70$.

Cartwright, W., Ruas, A. (2015). Mapping the world. International Journal of Cartography 1:1, pages 1-4, Conner, N. (2014). Geography of Sports. Oxford University Press.

Gaffney, C. (2015). 10 The urban impacts of the 2014 World Cup in Brazil. Mega-Events and Globalization: Capital and Spectacle in a Changing World Order, 167.

Gartner, G., Huang, H. (2016). Recent research developments in modern cartography in Europe. International Journal of Cartography, 2(1), 1-5.

Goldblatt, D. (2011). Football arte. Soccer \& Society, 12(1), 21-22.

Griffin, A.L., White, T., Fish, C., Tomio, B., Huang, H., Sluter, C.R., Meza Bravo, J.V., Fabrikant, S.I., Bleisch, S., Yamada, M., Picanço, P. (2017). Designing across map use contexts: A research agenda. International Journal of Cartography, 3(sup1), 90-114.

Henry, I. (2005). The governance of sport in Europe. European Journal of Sport Science, 5(4), 165.

Herman, G. V., Buhaș, S. D., Stance, L., \& Pop, A. (2016b). Considerations regarding the evolution, distribution and dynamics of the romanian football (League I) between 1989-2016. GeoSport for Society, 5(2), 69-78. 
Herman, G. V., Ilieș, D. C., Baias, Ș., Măduța, M. F., Ilieș, A., Wendt, J., \& Josan, I. (2016a). The tourist map, scientific tool that supports the exploration of protected areas, Bihor County, Romania. GeoSport for Society, 4(1), 24-32.

Herman, G. V., Szabo-Alexi, M., Szabo-Alexi, P., Dragoş, P. F., \& Marinău, M. (2018). The sport, vector of regionalization/globalization Case study: International Volleyball Federation (FIVB). GeoSport for Society, 8(1), 40-50.

Ilieș, A., Dehoorne, O., Wendt, J., \& Kozma, G. (2014). For geography and sport, sport geography or geography of sport. Geosport for Society, 1(1-2), 7-18.

Ilies, A., Ilieş, D. C., \& Deac, A. L. (2015). Selective, subjective or exclusive tourist map. GeoJournal of Tourism \& Geosites, 16(2), 217-226.

Ilies, A., Ilieș, M., \& Bulz, G. C. (2016c). History and Tradition on the Maramureș County football map (period 1980-2016). Geosport for Society, 5(2), 107-132.

Ilieș, A., Ilieș, M., \& Morariu, C. (2016b). Socialist heritage and symbols in football teams (1981-1989) in Maramureș County (Romania). GeoJournal of Tourism \& Geosites, 18(2), 259-269.

Ilies, A., Stance, L., \& Bulz, G. C. (2016a). Geographical landmarks for delimitation of sport-cultural space defined by amateur football in Crișana and Maramureș (2011-2016). Analele Universitatii din Oradea, Seria Geografie, 26(2), 223-234.

James, G., \& Day, D. (2015). FA Cup success, football infrastructure and the establishment of Manchester's footballing identity. Soccer \& Society, 16(2-3), 200-216.

Kozma, G., Bacs, Z., \& Zilinyi, Z. (2015). The possibilities and results for the scientific research into the relationship between settlements and sport. Geosport for Society, 3(2), 41-52.

Murphy, C. E. (2019). Designing the imagery on image maps-how far can we take it?. International Journal of Cartography, 1-16.

O'Brien, O., \& Cheshire, J. (2016). Interactive mapping for large, open demographic data sets using familiar geographical features. Journal of Maps, 12(4), 676-683.

Raisch, M. (2018). The Football Atlas: the illustrations putting the World Cup on the map (theguardian.com/football/these-football-times/2018/jun/25/football-atlas-illustrated-worldcup (retired 25 jun, 2018).

Reilly, T., \& Gilbourne, D. (2003). Science and football: a review of applied research in the football codes. Journal of sports sciences, 21(9), 693-705.

Robinson, A. C., Demšar, U., Moore, A. B., Buckley, A., Jiang, B., Field, K., Kraak, M.J., Camboim, Sluter, C. R. (2017). Geospatial big data and cartography: research challenges and opportunities for making maps that matter. International Journal of Cartography, 3(sup1), 32-60.

Roth, R. E., Çöltekin, A., Delazari, L., Filho, H. F., Griffin, A., Hall, A., Korpi, J., Lokka, I., Mendonça, A., Ooms, K., van Elzakker, C. P. (2017). User studies in cartography: opportunities for empirical research on interactive maps and visualizations. International Journal of Cartography, 3(sup1), 61-89.

Sam, M. P., \& Hughson, J. (2010). Sport in the city: cultural and political connections. Sport in Society, 13(10), 1417-1422.

Scutti, G., \& Wendt, J. A. (2016). Football and geopolitics. GeoSport for Society, 5(2), 100-106.

Shobe, H. (2008). Football and the politics of place: Football Club Barcelona and Catalonia, 19752005. Journal of cultural geography, 25(1), 87-105.

Vertinsky, P. A., \& Bale, J. (Eds.). (2004). Sites of sport: Space, place, experience. Psychology Press.

Web-sites sources:

1.ro.soccerway.com (retired in 12 July 2019 and 6 September, 2019) 